UDC 621.913

DOI: https://doi.org/10.26642/tn-2017-2(80)-67-72

\author{
S.V. Kovalevskyi, Dr. Sc., Professor \\ O.S. Kovalevska, Ph.D, Associate Professor \\ Donbas State Engeneering Academy, Kramatorsk, Ukraine
}

\title{
Engineering consulting technology in production engineering intelligent mobile machines
}

The article investigates the features of layout tools with parallel structure. A dynamic simulation model is developed; it allows the simulation of a given law of motion platform parallel mechanism and receive such valued characteristics as speed, acceleration platform, changing the torque on the front crank, reactionary force kinematics interaction mechanism of nodes. It allows you to make a decision of direct and inverse problems of dynamics c interactive visualization of spatial states of all moving parts of the implementation of precision movements programmed many systems coordination of movement. Classification and analysis of prospects for the use of automated manufacturing equipment based on industrial platforms with mechanisms of parallel structure were performed. It is established that the use of machines - robots based on these mechanisms can significantly increase the productivity and precision machining geometrically complex engineering products.

Keywords: parallel kinematics machines; neural networks; control; precision; neuron computers.

Introduction. A growing number of engineering companies that deal with improving the efficiency of processing hard core surfaces of machine parts, interested advancements in high-speed processing are appearing. Attempts of the implementation are hampered by several limitations caused by imperfect machines traditional layout based on the principles of serial kinematics. A classic example of such arrangement may be a machine $500 \mathrm{~V} / 5$ (Sterlitamak M.T.E.). The feature configurations of this type is that, given the trajectory of movement of the spindle axis defined serial displacement sled moving relative to each other.

Such arrangement has several drawbacks. First of all there is not enough machine rigidity that triggers the possibility of vibration during the cutting process, which reduces the quality of surface finish and tool stability.

The second important limiting factor is high inertia of mobile nodes. To disperse large mass of moving parts of the machine, this is typical for classic layout tools required long periods of time. High-speed processing is associated with the use of high feed speed, maximum acceleration and special treatment strategies that are characterized by a very large number of reversing drives. In the analysis of stable CNC processing program we evaluate the expected acceleration and if it exceeds a certain limit, the control system automatically lowers the value of supply not to disturb the trajectory. There is a drop in productivity and a violation of the cutting.

An effective solution to the problem that has arisen is to create tools based on parallel kinematic structure that provides consistent change of the lengths of rods, which holds executive body (the spindle hub). This principle has application and further development of machine-tool in the development of many companies, including rods with a length constant $[1$, p. 25].

Cutting equipment of this type is called "machine - a robot", because of the rod function arm robot, which determines the trajectory of the executive body.

Machine tools, kinematics are based on the principles of parallel kinematics, in theory, and have the following advantages:

- high rigidity that is provided by the emergence of a carrier system only tensile stress (compression) and parallel distribution efforts working in a closed kinematic structure, unlike open-loop kinematic structure classic layout tools;

- high dynamic performance due to low weight and distribution efforts in parallel motors;

- simplicity of design with the same type of parts, low metal content, and etc.

However, with the advantages of machine tools with parallel kinematic structure there are inherent disadvantages:

- nonlinear kinematic and dynamic characteristics of machines that require nonlinear control systems;

- dependence of static stiffness, gear ratios for effort and acceleration and dynamic properties of the actual position of the spindle;

- complex form of working space and reduced in comparison with traditional machines, the ratio of the working area and the area occupied by the machine;

- the analysis of the work of foreign researchers devoted to assessing stiffness machines with parallel kinematics, concluded that the rigidity of the existing machines with similar kinematics, depending on the design features, ranging from 5 to $200 \mathrm{~N} / \mathrm{m}$ and inferior in this characteristic tools of classical layout.

Scientific problem of handling mechanisms of parallel structure uniqueness and special changes remained significant impact on the performance of machines - robots and related technology systems, is relevant and solved, for example, through the development of industrial platforms with kinematic interchange [Figure 1]. 


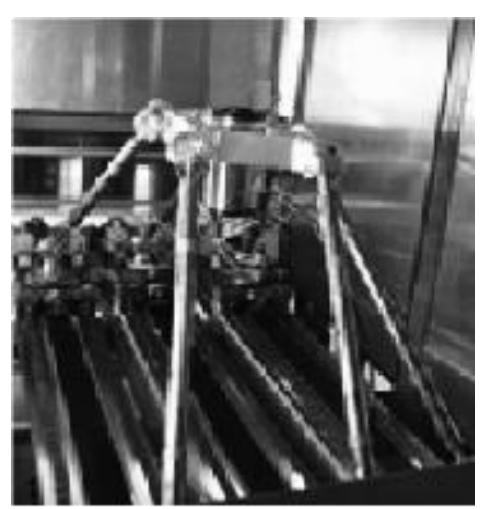

Fig. 1. Example of application of the mechanisms of parallel structure in machine tools

According to the company Siemens, which takes an active part in the development of machines with mechanisms of parallel structure, individual modules and control systems are the greatest consumer demand machine -work type Tricept (60\%), based on linapod (20\%) and hexapod (5\%) (Fig.4). It is expected that soon the total annual production of such machines will reach 3,300 units. Superiority in the creation and production of mechatronic systems is currently provided by highly "Hi-Tech" technology to countries such as Japan, Germany, USA, Sweden, France, Austria. Positioning accuracy of mass-produced machine tools, robots with mechanisms of parallel structure reaches $1 \ldots 5$ micron frequency spindle up to $30,000 \mathrm{~min}^{-1}$, the speed of movement industrial platform to $90 \mathrm{~m} / \mathrm{min}$, maximum speed up to $10 \mathrm{~m} / \mathrm{s}^{2}$, and when tested up to $50 \mathrm{~m} / \mathrm{s}^{2}$.

Despite the rapid development of unconventional machine hardware-based mechanisms of parallel structure, problems of kinematics and dynamics of industrial platforms, including the conditions of their operation in the positional and contour management, are researched enough. The mathematical formulas do not provide the opportunity to explore many links of kinematic parameters platform when mining the same path at different times and the ability to smoothly adjust the speed of the parts of the light gradient acceleration. Also the problem of modeling the aggregate trajectories platform for different load units with common or the engines consistent do not set conditions for the possible closure of spatial mechanism is not solved.

Methodology and materials. The problem of forecasting reliability indices mechanisms of parallel structure for the period estimated lifetime is relevant. Industrial platforms reliability analysis during the design and refinement of prototypes are impossible without computer simulation modeling, the bulk of which is to assess the efficiency of "weak element" in the industrial platforms criteria for disorders of functioning as a separate element, and the entire system in general. For similar systems it is not usually possible to establish the laws of distribution of integrated load characteristics, accuracy, durability, etc., because these tasks are advisable to decide on the method of statistical simulation (Monte Carlo), which provides a reliable assessment of disability in the absence or difficulty analytical solutions.

Adequate accuracy in predicting performance and reliability of industrial platforms in terms of their operation established during the project to research and bring in the prototypes is almost impossible without computer simulation [2, p.1]. In this case, the least developed and most difficult is the question of stability simulation modeling Lewis pole positioning and its orientation when the resonant modes, as well as in critical overload in an unfavorable combination of functional and structural parameters. Previous simulation modeling include functional and settlement and design analysis. Depending on the functionality of the module assembly unit, part or element of criteria set of efficiency and prescribe treatment with a further burden simulation modeling [3, p. 14].

For gears, bearings, seals and other heavy elements mechanical subsystem of statistical tests of extreme level the need to identify all areas of existence of each critical parameter disability weak element in the scattering spectrum loads and other actively influencing factors is eliminated. For certain low set element extreme test conditions there are the following groups of factors:

- in operation (speed, load, temperature, dust, etc.)

- the conditions of work (taking into account the possibility of contamination of surface friction, aging rubber seals and loss of lubrication, mechanical elastic vibrations, resonance phenomena, etc.)

- for the initial state of the object (precision manufacture and assembly, gaps in the joints of probabilistic estimation of extreme values within the tolerance stiffness related items at possible values, etc.).

In the initial data for modeling efficiency gears statistical distributions of random variables (parameters) that are tested in practice design verification techniques deterministic calculation capacity and ISO standards are included. Calculations include fatigue schematization of exercise regimes. Statistical tests of the extreme end of the definition of disability weak elements, while not identifying a possible implementation of emergency and extreme set of implementations and the law of their distribution in time, provided that the ability to predict resource. 
For the calculation of efficiency and reliability of statistical modeling by industrial platforms extreme pressures of weak level elements and perform simulation efficiency of weak elements modeling the performance of weak elements the criteria violations pursuant to the flowchart cyclical payments should be generated $[4$, p. 326].

For most designs of electromechanical industrial platforms in the calculation of the probability of failure of the system a series-parallel connection of elements and functions used to solve algebraic logic cannot be represented.

The parametric forecasting reliability mechanisms of parallel structure is performed by a linear model of the process in the joints wear parts and the method of statistical tests (Monte Carlo). The accuracy of positioning in the period of a given service life is established with a certain probability [5, p. 52].

Results and analysis. Construction of the coordinate system for the implementation of complex spatial displacement with high accuracy and dynamic performance requires a dynamic analysis of executive-level system, which refers to the actuator parallel kinematics, which has manufacturing moving, processing operations or measurement. During the dynamic analysis of actuator displacement coordinate system the problem of designing and implementing direct mathematical model that describes the dynamic state and behavior of the mechanism in motion and balance of power in the presence of external influences is solved; it is built on the basis of a dynamic model of the actuator solve direct and inverse problems of dynamics, modeling conducted in an environment of dynamic simulation models for specific cases testing actuator movement specified [6, p.52]. On the basis of results obtained during dynamic analysis, it is possible to determine the requirements and recommendations to the Governing engine displacement coordinate system as output characteristics of change of torque, velocity, acceleration, peak loads needed to implement a given law of motion of the actuator. Built dynamic model serves best for controller configuration and verification management system, as well as takes into account both dynamic and kinematic features of the actuator [7, p. 268].

We consider the example of dynamic analysis optopod, which structure is shown in Fig. 2.

This parallel mechanism is the most common case of structural performance of the above mentioned mechanisms of parallel kinematics [8, p. 48].

Within the dynamic analysis, direct and inverse problem solution of the dynamics of the actuator is made [9, p. 187]. Direct problem of dynamics is to determine the law of motion platform based on a given change in torque applied to the input crank actuator [10, p. 289]. Inverse dynamics is to determine the functional dependence of change of torque applied to the input crank actuator to implement a given law of motion platform.

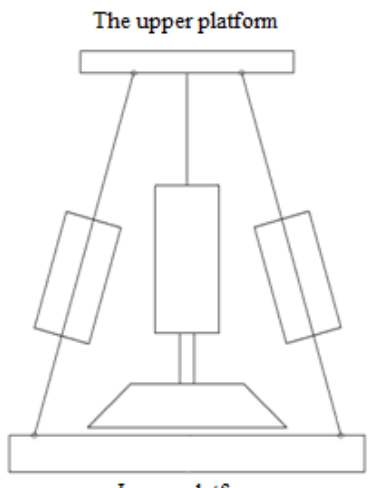

Lower platform
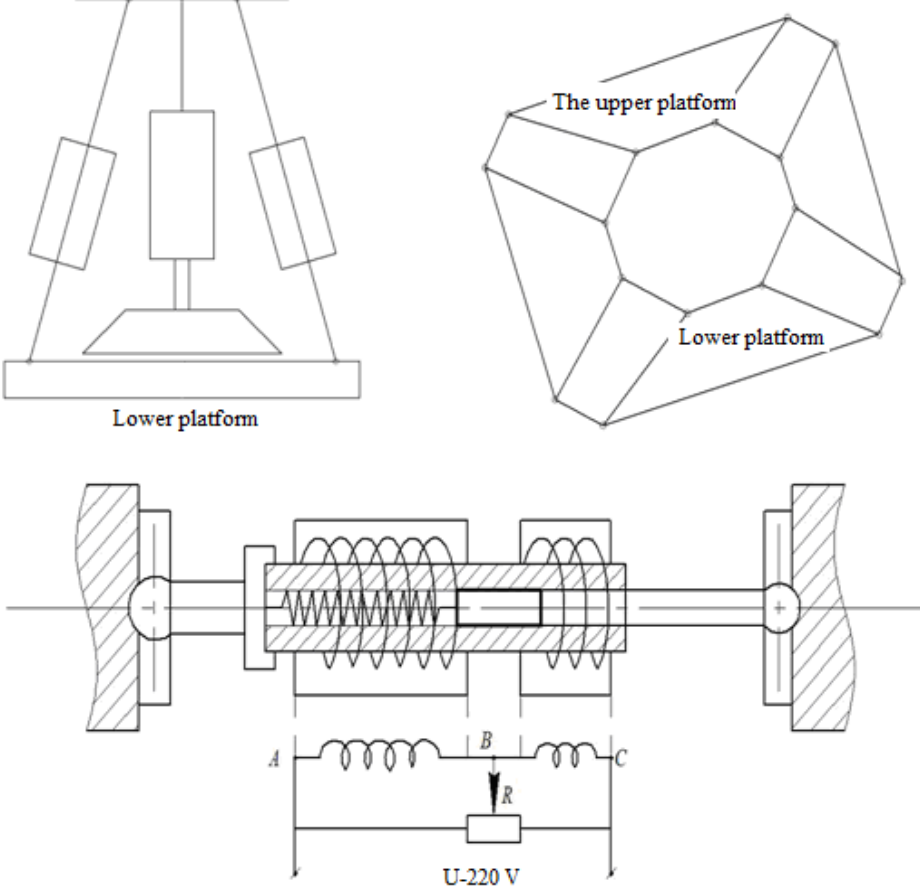

Fig. 2. Block diagram optopod

In Fig. 3 clearly shows the solution of direct and inverse problems of dynamics, based on a dynamic model of the actuator. 


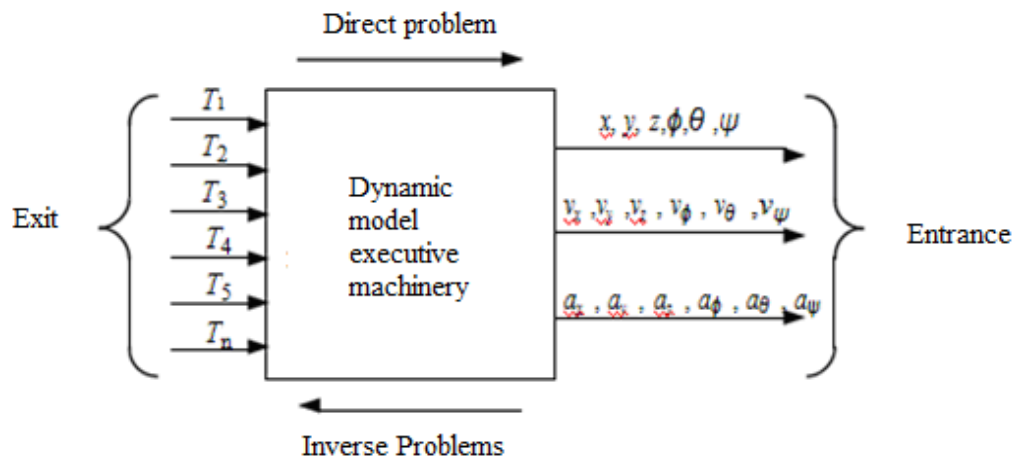

Fig. 3. Diagram solution of direct and inverse problems of dynamics

To move the platform mechanism we proposed dynamic simulation model of management of the structural scheme presented in Fig. 4.

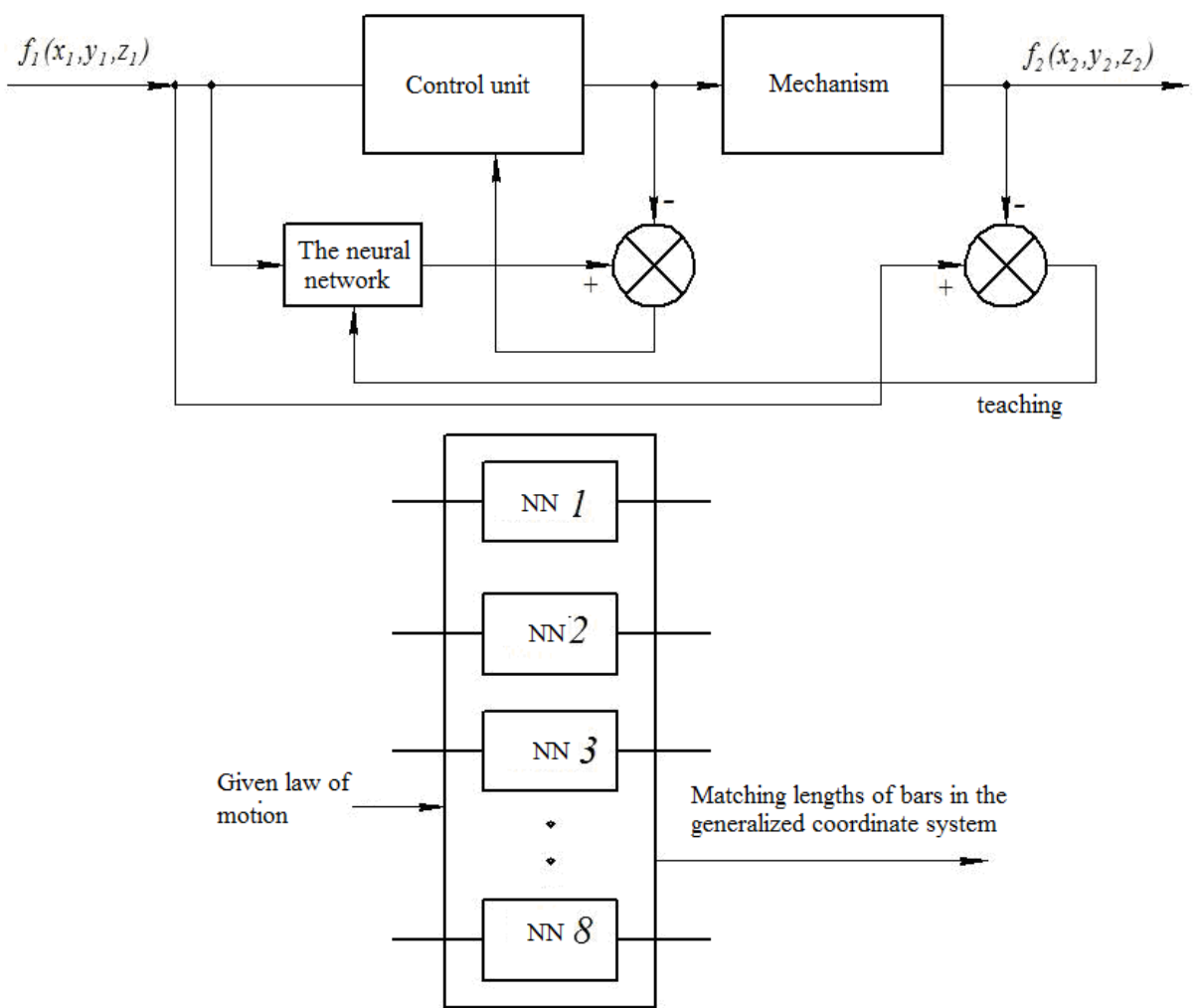

Fig. 4. Scheme of dynamic simulation models of parallel control mechanism

Immediate implementation of dynamic simulation models of parallel control mechanism in MATLAB Simulink environment is presented in Fig. 5.

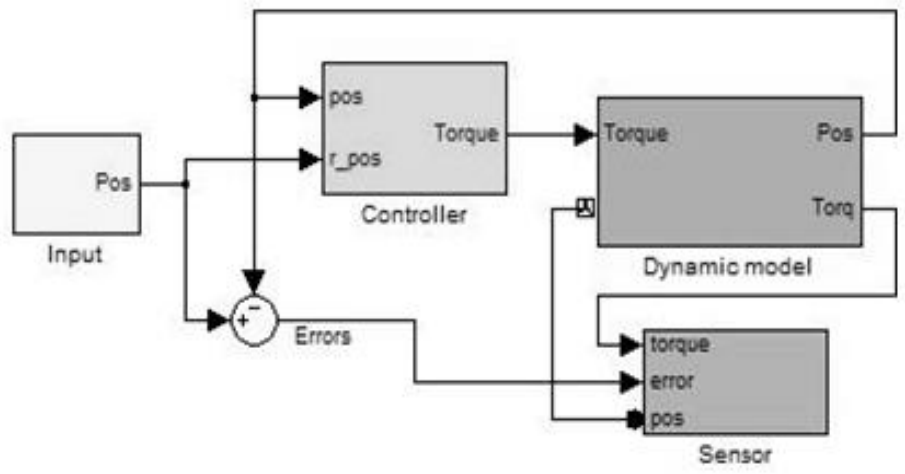

Fig. 5. Dynamic simulation model of parallel control mechanism in the environment MATLAB / Simulink 
Conclusions. According to Fig. 8 input function block sets the law of motion platforms and calculates the generalized angular coordinates input crank mechanism by solving the inverse problem of kinematics, the unit acts as a regulator controller, dynamic model as a dynamic model of parallel mechanism, sensor gives a conclusion and performance of dynamic models.

The developed simulation dynamic model allows the simulation of a given law of motion platform parallel mechanism and receive such valued characteristics tend to speed, acceleration platform, changing the torque on the front crank, reactionary force kinematics interaction mechanism of nodes. It allows to make a decision of direct and inverse problems of dynamics of interactive visualization of spatial states of all moving parts of the implementation of precision movements programmed many systems coordination of movement.

Classification and analysis of prospects for the use of automated manufacturing equipment based on industrial platforms with IPS are performed. It is established that the use of IPS based machines - robots can significantly increase the productivity and precision of machining geometrically complex engineering products. Also clearly expressed tendency to use machine tools, the layout of which is based on the principles of parallel and hybrid kinematics so as to reduce the size and weight and are of potentially large specific rigidity, increased dynamic performance, ease of manufacturability and design.

\section{Список використаної літератури:}

1. Гутыря С.С. Механизмы параллельной структуры в современном машиностроительном производстве / С.С. Гутыря, В.П. Яглинский // Технологічні комплекси : наук. журнал. - 2010. - № 2. - С. 25-35.

2. V100 // INDEX : сайт. - 2011 [Электронный pecypc]. - URL : http://www.indexwerke.de/de/englisch/546_ENG_HTML.htm.

3. Кузнєцов Ю.М. Компоновки верстатів 3 механізмами паралельної структури / Ю.М. Кузнєцов, Д.О. Дмитрієв, Г.Ю. Діневич. - Херсон : ПП Вишемирський В.С., 2009. - 456 с.

4. Яәлінський В.П. Кінематика і параметрична надійність роботів паралельної структури / В.П. Яглінський // Методи розв'язування прикладних задач механіки деформованого твердого тіла : зб. наук. пр. Дніпропетровськ : Наука і освіта, 2010. - Вип. 11. - С. 324-331.

5. Надежность промышленных роботов в экстремальных условиях нагружения / С.С. Гутыря, В.П. Яалинский, Г.А. Оборский, Д.Н. Хлицов // Проблеми обчислювальної механіки і міцності конструкцій : зб. наук. пр. Дніпропетровськ : IMA-прес, 2009. - Вип. 13. - С. 50-56.

6. Карпович С.Е. Прецизионные системы перемещений / С.Е. Карпович, Ю.С. Межинский, В.В. Жарский // Доклады БГУИР. - 2004. - № 3 (7). - С. 50-61.

7. Литвинов E.A. Моделирование динамики параллельного механизма с шестью степенями свободы в среде MATLAB / Simulink / E.A. Литвинов // Теоретическая и прикладная механика. - 2009. - № 24. - С. 267-272.

8. Petrenko Y.I. Research of algorithms and development of modeling and simulation technique of automatic control systems in 20-sim / Y.I. Petrenko // Матеріали XVII науково-технічної конференції студентів, магістрантів, аспірантів і викладачів. - Запоріжжя : ЗДІА, 2013. - С. 48-49.

9. Колесов Ю.В. Моделирование систем. Динамические и гибридные системы : учеб. пособие / Ю.Б. Колесов, Ю.Б. Сениченков. - СПб. : БХВ-Петербург, 2006. - 226 с.

10. Гапоненко E.B. Моделирование динамики паралельного робота и оценка точности позиционирования / E.В. Гапоненко, Л.А. Рыбак // Вибрационные технологии, мехатроника и управляемые машины : сб-к науч. статей XI научно-технической конференции «Вибрация - 2014». - Курск, 2014. - Ч. 2. - С. 288-293.

\section{References:}

1. Gutyrja, S.S. and Jaglinskij, V.P. (2010), «Mehanizmy parallel'noj struktury v sovremennom mashinostroitel'nom proizvodstve», Tehnologichni kompleksi, nauk. zhurnal, No. 2, pp. 25-35.

2. «V100» (2011), INDEX, sajt, available at: URL: http://www.index-werke.de/de/englisch/546_ENG_HTML.htm

3. Kuznjecov, Ju.M., Dmytrijev, D.O. and Dinevych, G.Ju. (2009), Komponovky verstativ z mehanizmamy paralel'noi' struktury, PP Vyshemyrs'kyj V.S., Herson, $456 \mathrm{p}$.

4. Jaglins'kyj, V.P. (2010), «Kinematyka i parametrychna nadijnist' robotiv paralel'noi' struktury», Metody rozv'jazuvannja prykladnyh zadach mehaniky deformovanogo tverdogo tila, zb. nauk. pr., Nauka i osvita, Dnipropetrovs'k, Vol. 11, pp. 324-331.

5. Gutbrja, S.S., Jaglynskyj, V.P., Oborskyj, G.A. and Hlycov, D.N. (2009), «Nadezhnost' promыshlennыh robotov v эkstremal'nыh uslovyjah nagruzhenyja», Problemy obchysljuval'noi' mehaniky i micnosti konstrukcij, zb. nauk. pr., Vol. 13, IMA-pres, Dnipropetrovs'k, pp. 50-56.

6. Karpovych, S.E., Mezhynskyj, Ju.S. and Zharskyj, V.V. (2004), «Precyzyonnыe systemы peremeshhenyj», Dokladbl BGUYR, No. 3 (7), pp. 50-61.

7. Lytvynov, E.A. (2009), «Modelyrovanye dynamyky parallel'nogo mehanyzma s shest'ju stepenjamy svobodы v srede MATLAB / Simulink», Teoretycheskaja y prykladnaja mehanyka, No. 24, pp. 267-272.

8. Petrenko, Y.I. (2013), «Research of algorithms and development of modeling and simulation technique of automatic control systems in 20-sim», Materialy XVII naukovo-tehnichnoi' konferencii' studentiv, magistrantiv, aspirantiv $i$ vykladachiv, ZDIA, Zaporizhzhja, pp. 48-49.

9. Kolesov, Ju.V. and Senichenkov, Ju.B. (2006), Modelirovanie sistem. Dinamicheskie i gibridnye sistemy, BHV-Peterburg, $\mathrm{SPb}$., $226 \mathrm{p}$. 
10. Gaponenko, E.V. and Rybak, L.A. (2014), «Modelirovanie dinamiki paralel'nogo robota i ocenka tochnosti pozicionirovanija», Vibracionnye tehnologii, mehatronika i upravljaemye mashiny, sb-k nauch. statej XI nauchnotehnicheskoj konferencii «Vibracija - 2014», Kursk, Part 2, pp. 288-293.

Kovalevskyy Sergiy Vadimovich - Dr. Sc., Professor, Head of the department Technology of mechanical engineering, Donbas State Engendering Academy, Kramatorsk, Ukraine.

Scientific interests:

- parallel kinematics machines;

- neural networks;

- engineering technology.

Kovalevska Olena Sergiivna - Ph.D, Associate Professor of department of Technology of mechanical engineering, Donbas State Engendering Academy, Kramatorsk, Ukraine.

Scientific interests:

- parallel kinematics machines;

- neural networks.

E-mail: olenakovalevskaya@gmail.com

Article was received by the editorial staff 04.09.2017. 